\title{
Protoplast Transformation of Bacillus licheniformis MC14
}

\author{
By KARREN K. JENSEN AND F. MARION HULETT* \\ Laboratory for Cell, Molecular, and Developmental Biology, University of Illinois at Chicago, \\ Chicago, Illinois 60680, USA
}

(Received 23 November 1988; revised 18 April 1989; accepted 5 May 1989)

A protoplast transformation system has been developed for Bacillus licheniformis MC14. Optimum regeneration conditions were achieved by raising the incubation temperature of the regeneration plates to $46^{\circ} \mathrm{C}$. Regenerated transformed colonies could be isolated in 3 to $5 \mathrm{~d}$ under these conditions. Plasmids introduced by this method were stably maintained by B. licheniformis $\mathrm{MCl} 4$ and could be recovered and used to transform Bacillus subtilis.

\section{INTRODUCTION}

Alkaline phosphatase (APase) has been well studied in both Gram-negative (Escherichia coli) and Gram-positive (Bacillus subtilis and Bacillus licheniformis) systems. This enzyme is produced and secreted from cells which are subjected to phosphate-limiting growth conditions. The study of APase therefore encompasses inquiry into such mechanisms as the regulation of stress responses, the mechanism of protein secretion, and interactions between various environmental response systems.

B. licheniformis $\mathrm{MC} 14$ has been extensively used in our laboratory to study APase. This strain, which synthesizes 15 times more APase activity than has been reported for other Bacillus species (Hulett \& Campbell, 1971; Spencer et al., 1981), is an excellent system for biochemical studies of this enzyme. It does not, however, have an established transformation system. Our first goal was to develop a reliable transformation system for B. licheniformis MC14 in order to probe the relationship between multiple structural APase genes and multiple gene product destinations through recombinant DNA methods (Hulett, 1987). We have achieved transformation of B. licheniformis MC14 using a modified version of the Chang \& Cohen (1979) B. subtilis protoplast transformation protocol. Plasmid DNA can be recovered from transformed cells without apparent deletions or rearrangements.

\section{METHODS}

Bacterial strains and plasmids. Bacillus licheniformis strain MC14 (Hulett \& Campbell, 1971) was used for all transformation procedures. Plasmid pBC16 carrying a Gram-positive tetracycline-resistance gene was used for transformation (Bernhard et al., 1978).

Media. All media used for protoplast transformation procedures were as described by Chang \& Cohen (1979). Penassay broth (per litre: $4 \mathrm{~g}$ Difco nutrient broth, $2.5 \mathrm{~g}$ peptone, $1.5 \mathrm{~g}$ yeast extract, $3.5 \mathrm{~g} \mathrm{NaCl}, 1.32 \mathrm{~g} \mathrm{KH}_{2} \mathrm{PO}_{4}$, $3.68 \mathrm{~g} \mathrm{~K}_{2} \mathrm{HPO}_{4}$ ) was supplemented with $0.1 \%(\mathrm{w} / \mathrm{v})$ glucose. $2 \times \mathrm{SMM}$ medium consisted of $1 \mathrm{M}$-sucrose, $0.04 \mathrm{M}$-maleic acid and $0.04 \mathrm{M}-\mathrm{MgCl}_{2}$ at $\mathrm{pH} 6.5$. DM3 (for regeneration plates) contained the following sterile solutions : $200 \mathrm{ml} \mathrm{4 \%}$ (w/v) agar, $500 \mathrm{ml} 1 \mathrm{M}$-sodium succinate (pH 7.3), $100 \mathrm{ml} 5 \%(\mathrm{w} / \mathrm{v})$ Casamino acids, $50 \mathrm{ml}$ $10 \%(\mathrm{w} / \mathrm{v})$ yeast extract, $100 \mathrm{ml} \mathrm{3.5 \% (w/v)} \mathrm{K}_{2} \mathrm{HPO}_{4}, 100 \mathrm{ml} \mathrm{1.5 \%} \mathrm{KH}_{2} \mathrm{PO}_{4}, 25 \mathrm{ml} \mathrm{20} \%$ (w/v) glucose, $20 \mathrm{ml} 1 \mathrm{M}-$ $\mathrm{MgCl}_{2}$ and $5 \mathrm{ml}$ filter-sterilized $2 \%(\mathrm{w} / \mathrm{v})$ bovine serum albumin. Mannitol-based regeneration medium was as determined by Gray \& Chang (1981). A sorbitol-based regeneration medium was made by replacing mannitol with sorbitol in the preceding medium. LB medium was made according to Maniatis et al. (1982). 
Transformation. Protoplast transformation was performed according to the method of Chang \& Cohen (1979) as follows. The modifications made by us are noted under Results and Discussion. A culture of B. licheniformis MC14 was grown overnight in $5 \mathrm{ml} \mathrm{LB}$ medium broth supplemented with glucose to $1 \%(\mathrm{w} / \mathrm{v})$; then $1 \mathrm{ml}$ of this culture was inoculated into $50 \mathrm{ml}$ of $1 \times$ penassay broth and grown to an $\mathrm{OD}_{540}$ of about 0.5 with agitation at $37^{\circ} \mathrm{C}$. Cells from $40 \mathrm{ml}$ of this culture were pelleted in a clinical centrifuge and resuspended in $4 \mathrm{ml} \mathrm{SMMP}(1$ vol. $2 \times$ SMM added to 1 vol. $4 \times$ penassay broth). This culture was subdivided into two cultures of $2 \mathrm{ml}$. One culture (control) received no lysozyme and the second culture received $0.5 \mathrm{ml}$ filter-sterilized lysozyme $\left(20 \mathrm{mg} \mathrm{ml}^{-1}\right)$ in SMMP. Both cultures were shaken for about $1 \mathrm{~h}$ at room temperature and protoplast formation was determined microscopically. When no whole cells were observed, protoplasts were pelleted in the clinical centrifuge, washed twice with $2 \mathrm{ml}$ SMMP and finally resuspended in $1 \mathrm{ml}$ SMMP. Protoplasts were subdivided into $0.5 \mathrm{ml}$ aliquots, one of which (control) received no additions while the other received 10-100 $\mathrm{g}$ DNA. Cultures were treated with $1.5 \mathrm{ml} 40 \%$ $(\mathrm{w} / \mathrm{v})$ polyethylene glycol (PEG) for $2 \mathrm{~min}$ at room temperature and diluted by adding $5 \mathrm{ml} \mathrm{SMMP}$. The cultures were then pelleted in the clinical centrifuge, resuspended in $1 \mathrm{ml} \mathrm{SMMP,} \mathrm{diluted,} \mathrm{and} \mathrm{plated} \mathrm{to} \mathrm{DM3} \mathrm{(or} \mathrm{other)}$ regeneration medium. Regeneration plates were incubated at $46^{\circ} \mathrm{C}$ for $3-5 \mathrm{~d}$ in loosely closed plastic bags to retard moisture loss.

DNA isolation. Chromosomal DNA was isolated according to the method of Schleif \& Wensink (1981). Plasmid DNA was isolated from $B$. licheniformis transformants according to the method of Gryczan et al. (1978).

\section{RESULTS AND DISCUSSION}

\section{Development of the protoplast regeneration method}

Bacillus licheniformis MC14 could not be transformed by competent cell transformation systems used for Bacillus subtilis. Other transformation systems developed for various Bacillus species, incuding cell mating in liquid culture (Landman \& Pepin, 1982), filter mating with E. coli (Van Randen \& Venema, 1984), and direct plasmid transfer (Gonzalez \& Carlton, 1982), were also unsuccessful.

Since these transformation systems were not available for transformation of $B$. licheniformis MC14 we investigated the use of a protoplast transformation system in this strain. We began with the protocol established by Chang \& Cohen (1979) for the transformation of $B$. subtilis. Our initial attempt failed because we were unable to establish conditions under which the $B$. licheniformis $\mathrm{MC1} 4$ protoplasts would regenerate. Instead, after about $48 \mathrm{~h}$ incubation at $37^{\circ} \mathrm{C}$ on succinate-based regeneration plates, L-form colonies appeared. These consisted of protoplasts with little or no cell wall material. These L-form cells were able to grow and divide in the absence of a cell wall. The colonies of L-forms were very small $(<1 \mathrm{~mm})$, hard, and partially embedded in the agar. Individual cells appeared as phase-bright spheres or, very rarely, as a sphere with a small tail. The colonies could not be replica-plated or picked. Continued incubation at $37^{\circ} \mathrm{C}$ failed to produce normal cells. When entire colonies were excised from the regeneration medium and transplanted to a mannitol- or sorbitol-based regeneration medium (Gray \& Chang, 1981) normal cells were regenerated within $24-36 \mathrm{~h}$ at $37^{\circ} \mathrm{C}$. Direct plating on this mannitol-or sorbitol-based medium following transformation failed to produce any colony growth. Therefore, we needed to alter conditions to achieve regeneration of these L-form colonies.

Several variations of the succinate-based regeneration medium were tested. We have found that $B$. licheniformis MC14 grows well in high-salt conditions, requires citrate as a component in a chemically defined medium, and is enhanced in growth by DL-alanine. Each of these components was added to the succinate-based regeneration medium: plates were formulated containing $50 \mathrm{mM}$ - or $100 \mathrm{~mm}-\mathrm{NaCl}, 50 \mathrm{~mm}$-sodium citrate, or $50 \mu \mathrm{g} \mathrm{DL}$-alanine $\mathrm{ml}^{-1}$. None of these additions accomplished the desired effect of stimulating regeneration of $L$-form colonies. In addition, mannitol or sorbitol $\left(40 \mathrm{~g} \mathrm{l}^{-1}\right)$ was added as a supplement to the succinate-based regeneration medium without apparent improvement of regeneration. Bourne \& Dancer (1986) reported an improvement in regeneration of $B$. licheniformis protoplasts when gelatin was used as the sole gelling agent for regeneration plates. This did not, however, prove true for B. licheniformis MC14.

B. licheniformis $\mathrm{MC14}$ is a facultative thermophile capable of growth at temperatures up to $60^{\circ} \mathrm{C}$. The normal culture conditions under which APase is assayed in liquid defined medium 
include an incubation temperature of $50^{\circ} \mathrm{C}$, at which excellent growth occurs. Chen et al. (1986) achieved successful protoplast regeneration in the thermophilic species Bacillus stearothermophilus by incubating succinate-based regeneration plates at $60^{\circ} \mathrm{C}$. By analogy we elevated the incubation temperature for regeneration plates of $B$. licheniformis. At $37^{\circ} \mathrm{C}$, the normal incubation temperature for growth of $B$. licheniformis on plates, no L-form colonies could be seen on regeneration plates until 40 to $48 \mathrm{~h}$ of incubation. These $\mathrm{L}$-form colonies failed to regenerate upon extended incubation for up to $5 \mathrm{~d}$. Raising the incubation temperature to $42^{\circ} \mathrm{C}$ resulted in the appearance of $\mathrm{L}$-form colonies on the regeneration plates within $20 \mathrm{~h}$. After $40-48 \mathrm{~h}$ at $42^{\circ} \mathrm{C}$ about $1 \%$ of these L-form colonies had regenerated to normal bacilliform cells, and after $5 \mathrm{~d}$ about $10 \%$ of the L-form colonies had regenerated. A $46^{\circ} \mathrm{C}$ incubation temperature for regeneration plates also resulted in the appearance of $L$-form colonies within $20 \mathrm{~h}$ but about $10 \%$ of these $\mathrm{L}$-forms regenerated within $40-48 \mathrm{~h}$. Incubation for $5 \mathrm{~d}$ at $46{ }^{\circ} \mathrm{C}$ resulted in regeneration of virtually $100 \%$ of the L-form colonies. These L-form colonies represented approximately 1 in 1000 of the protoplasted cell population. Higher temperatures were also tried (up to $50^{\circ} \mathrm{C}$; data not shown) but these did not yield any improvement in regeneration speed over $46^{\circ} \mathrm{C}$. Higher temperatures also have the additional disadvantage of encouraging the growth of spreading colonies, probably derived from unprotoplasted whole cells, which overgrow the plate and inhibit the growth of regenerants.

\section{Protoplast transformation experiments}

These relatively efficient regeneration conditions allowed us to perform transformation of B. licheniformis MC14. A plasmid capable of replication in Bacillus (pBC16; Bernhard et al., 1978) carrying a tetracycline-resistance marker was selected for this transformation study because $B$. licheniformis MC14 is highly sensitive to tetracycline and it can be used in the regeneration medium for direct selection of transformants. We used $10 \mu \mathrm{g}$ of intact plasmid $\mathrm{pBC} 16$ to transform $B$. licheniformis $\mathrm{MC1} 4$ and isolated tetracycline-resistant colonies from each transformation by direct selection. Transformation efficiency using $10 \mu \mathrm{g}$ of CsCl-purified pBC16 was calculated as follows: (no. of transformants)/(no. of viable protoplast regenerants) $\times$ 100. Every $10^{8}$ cells protoplasted yielded about $10^{5} \mathrm{~L}$-form-colony-forming protoplasts and, of these, about $10^{2}$ were transformants. This gave a transformation efficiency of $0.1 \%$, which was consistent to $\pm 0.05 \%$ for 27 transformations. Our data for transformants of $\mathrm{pBC} 16$ which were regenerated nonselectively and then picked to Tryptose Blood Agar (Difco) plates supplemented with antibiotic indicated that about $0.1 \%$ of the regenerated colonies were resistant to the antibiotic when $10 \mu \mathrm{g}$ of DNA was used. These numbers are consistent with those obtained from direct selection. The transformants were confirmed as containing $\mathrm{pBC} 16$ by isolation of plasmid DNA by a quick-screen procedure (Gryczan et al., 1978). Plasmid DNA was obtained from 5-10 transformants from each of 27 transformations. The $\mathrm{pBC} 16$ isolated from the transformants appeared to be identical to the parent plasmid, as judged by the EcoRI digestion pattern (two fragments, of $3.2 \mathrm{~kb}$ and $1.7 \mathrm{~kb}$ ). For 12 of the isolates, the HindIII and PstI digestion patterns were also confirmed as identical to that of $\mathrm{pBC} 16$. Plasmid DNA introduced into $B$. licheniformis $\mathrm{MCl} 4$ by this method thus appears to be stably maintained and can be recovered without apparent deletions or rearrangements. Plasmid pBC16 DNA isolated from transformed $B$. licheniformis was used successfully to transform competent $B$. subtilis, further suggesting that the plasmid was unaltered. Five micrograms of $\mathrm{pBCl} 6$ plasmid DNA isolated from $B$. licheniformis $\mathrm{MC14}$ by the quick-screen procedure had the same transformation efficiency as $1 \mu \mathrm{g}$ of $\mathrm{CsCl}$-purified DNA from B. subtilis and yielded about $100 \mathrm{~B}$. subtilis transformants per $\mu \mathrm{g}$ DNA.

We were unable to select for Bacillus plasmids carrying a chloramphenicol-resistance marker because our strain is chloramphenicol resistant. We were also unsuccessful in using a plasmid carrying a kanamycin-resistance marker because kanamycin selection cannot be performed under these conditions. Grosch \& Wollweber (1982) reported that increasing the concentration of kanamycin in the succinate-based regeneration medium from 20 to $300 \mu \mathrm{g} \mathrm{ml}^{-1}$ would effect the desired selection. We found, however, that concentrations up to $2 \mathrm{mg} \mathrm{ml}^{-1}$ were ineffective and therefore abandoned using kanamycin in any direct selection of transformed protoplasts. It 


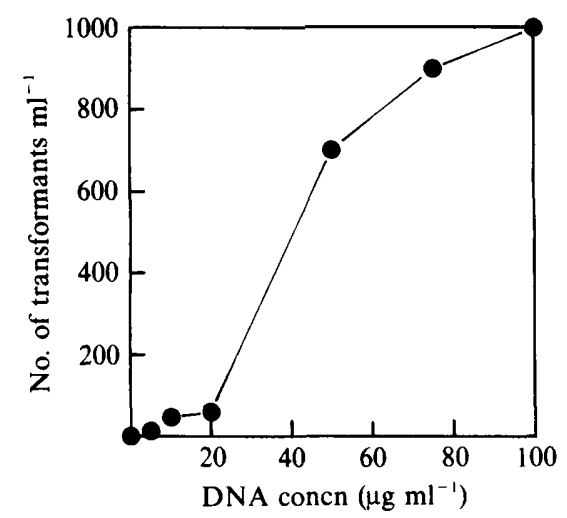

Fig. 1. Effect of varying DNA concentration on transformation efficiency. Number of transformants $\mathrm{ml}^{-1}$ was calculated by multiplying the number of transformants by the dilution factor for each plate and standardizing the figure per $\mathrm{ml}$ of protoplasts. The total volume for each protoplast preparation before plating was $1 \mathrm{ml}$ (see Methods).

is possible that under our incubation conditions $\left(46^{\circ} \mathrm{C}\right)$ kanamycin is inactivated in this medium. In the case of the tetracycline and erythromycin (pFB9; Barany et al., 1982, and data not shown) markers which we did use, we were able to select transformants for antibiotic resistance directly on the regeneration plates.

In order to maximize the efficiency of our transformation procedure, we examined the effect of varying the amount of $\mathrm{pBC} 16$ plasmid DNA used per transformation. This study was carried out under the conditions outlined above, regenerating protoplasts at $46^{\circ} \mathrm{C}$ on succinate-based plates supplemented with $10 \mu \mathrm{g}$ tetracycline $\mathrm{ml}^{-1}$. The results are summarized in Fig. 1 . The highest DNA concentration tested, $100 \mu \mathrm{g} \mathrm{m}^{-1}$, gave about $1 \%$ transformation efficiency.

We explored methods to try to reduce the concentration of DNA required to achieve efficient transformation. DeCastro-Costa \& Landman (1977) suggested that an inhibitory protein present in protoplasts of $B$. subtilis retards the reversion of protoplasts to whole cells by disrupting cell wall formation. We reasoned that a nuclease might also be present in the $B$. licheniformis protoplast preparation, increasing the amount of DNA required for successful transformation. To test these possibilities, we treated the protoplasts for $30 \mathrm{~min}$ at room temperature with $10 \mathrm{mg}$ protease $\mathrm{K} \mathrm{ml}^{-1}$. This did not increase transformation efficiency. We also tested to determine if PEG pretreatment would further permeabilize the protoplasts to DNA, resulting in a more efficient uptake of DNA. Pretreating the protoplasts with PEG for 2 min, washing the protoplasts, and then treating them with PEG in the presence of DNA also did not increase the efficiency of transformation.

In summary, successful protoplast transformation requires both efficient regeneration of protoplasts and efficient utilization of DNA in the transformation process. We have found that the most limiting step in our transformation procedure was the regeneration of protoplasted cells, which occurs in two steps: formation of L-form colonies and regeneration of these L-form colonies to normal bacilliform cells. As can be seen in our calculations of transformation efficiency, there is a $1 \%$ survival rate in the protoplast population that establishes L-form colonies. Once $\mathrm{L}$-forms are present, continued incubation at $46^{\circ} \mathrm{C}$ results in complete regeneration of virtually $100 \%$ of this population. The efficient utilization of DNA by the protoplasts undergoing transformation is accomplished by adding $100 \mu \mathrm{g}$ of DNA to the protoplasts in the presence of PEG, which results in about $1 \%$ of the regenerating $L$-forms being transformants. The conditions we have outlined here are very useful for the efficient and rapid isolation of transformants of $B$. licheniformis MC14 carrying plasmid DNA. 


\section{REFERENCES}

Barany, F., Boeke, J. D. \& Tomasz, A. (1982). Staphylococcal plasmids that replicate and express erythromycin resistance in both Streptococcus pneumoniae and Escherichia coli. Proceedings of the National Academy of Sciences of the United States of America 79, 2991-2995.

Bernhard, K., Schrempf, H. \& Goebel, W. (1978). Bacteriocin and antibiotic resistance plasmids in Bacillus cereus and Bacillus subtilis. Journal of Bacteriology 133, 897-903.

BOURNE, N. \& DANCER, B. N. (1986). Regeneration of protoplasts of Bacillus subtilis 168 and closely related strains. Journal of General Microbiology 132, 251255.

Chang, S. \& Cohen, S. N. (1979). High frequency transformation of Bacillus subtilis protoplasts by plasmid DNA. Molecular and General Genetics 168, 111-115.

Chen, Z., Wojcik, S. F. \& Welker, N. E. (1986). High frequency transformation of Bacillus stearothermophilus by protoplast fusion. Journal of Bacteriology 165, 994-1001.

DeCastro-Costa, M. \& Landman, O. (1977). Inhibitory protein controls the reversion of protoplasts and L forms of Bacillus subtilis to the walled state. Journal of Bacteriology 129, 678-689.

Gonzalez, J. M., JR \& Carlton, B. C. (1982). Plasmid transfer in Bacillus thuringiensis. In Genetic Exchange, pp. 85-95. Edited by U. N. Streips, S. H. Goodgal, W. R. Guild \& G. A. Wilson. New York: Marcel Dekker.

Gray, O. \& Chang, S. (1981). Molecular cloning and expression of Bacillus licheniformis $\beta$-lactamase gene in Escherichia coli and Bacillus subtilis. Journal of Bacteriology 145, 422-428.

GROSCH, J. C. \& Woll Weber, K. L. (1982). Transformation of Bacillus licheniformis and Bacillus amyloliquefaciens protoplasts by plasmid DNA. In Genetic
Exchange, pp. 97-105. Edited by U. N. Streips, S. H. Goodgal, W. R. Guild \& G. A. Wilson. New York: Marcel Dekker.

Gryczan, T. J., Contente, S. \& Dubnau, D. (1978). Characterization of Staphylococcus aureus plasmids introduced by transformation into Bacillus subtilis. Journal of Bacteriology 134, 318-329.

HulETT, F. M. (1987). Alkaline phosphatase from Bacillus licheniformis: proteins and genes. In Phosphate Metabolism and Cellular Regulation in Microorganisms, pp. 43-48. Edited by A. Torriani-Gorini, F. Rothman, S. Silver, A. Wright \& E. Yagil. Washington, DC: American Society for Microbiology.

Hulett, F. M. \& CAMpbell, L. L. (1971). Purification and properties of an alkaline phosphatase of Bacillus licheniformis. Biochemistry 10, 1364-1370.

Landman, O. E. \& PePIN, R. A. (1982). Bacillus subtilis mating system: dicaryotic recombinants and suppression of the prototropic phenotype. In Molecular Cloning and Gene Regulation in the Bacilli, pp. 25-39. Edited by A. T. Ganesman, S. Chang \& J. A. Hoch. New York: Academic Press.

Maniatis, T., Fritsch, E. F. \& Sambrook, J. (1982). Molecular Cloning: a Laboratory Manual, p. 440. Cold Spring Harbor, NY: Cold Spring Harbor Laboratory.

SCHLIEF, R. F. \& Wensink, P. (1981). Working with nucleic acids. In Practical Methods in Molecular Biology, pp. 98-99. New York: Springer-Verlag.

SPENCER, D. B., Chen, C.-P. \& HuleTt, F. M. (1981). Effect of cobalt on synthesis and activation of Bacillus licheniformis phosphatase. Journal of Bacteriology 145, 926-933.

VAN RANDEN, J. \& Venema, G. (1984). Direct plasmid transfer from replica plated $E$. coli colonies to competent Bacillus subtilis cells. Molecular and General Genetics 195, 57-61. 